This item was submitted to Loughborough's Research Repository by the author.

Items in Figshare are protected by copyright, with all rights reserved, unless otherwise indicated.

\title{
Protecting private transnational authority against public intervention: FIFA's power over national governments
}

PLEASE CITE THE PUBLISHED VERSION

http://dx.doi.org/10.1111/padm.12208

PUBLISHER

(c) Wiley

VERSION

AM (Accepted Manuscript)

\section{PUBLISHER STATEMENT}

This work is made available according to the conditions of the Creative Commons Attribution-NonCommercialNoDerivatives 4.0 International (CC BY-NC-ND 4.0) licence. Full details of this licence are available at: https://creativecommons.org/licenses/by-nc-nd/4.0/

\section{LICENCE}

CC BY-NC-ND 4.0

\section{REPOSITORY RECORD}

Garcia-Garcia, Borja, and Henk-Erik Meier. 2015. "Protecting Private Transnational Authority Against Public Intervention: Fifa's Power over National Governments". Loughborough University. https://hdl.handle.net/2134/18622. 


\title{
Protecting Private Transnational Authority against Public Intervention: FIFA's Power over National Governments
}

\author{
Borja García García (Loughborough University, UK) \\ Henk-Erik Meier (University of Münster, Germany)
}

\begin{abstract}
Scholars have controversially discussed whether the rise of transnational private authority is beneficial or undermines public legitimate authority. While the recent focus on civil regulation has emphasized the key role of public authorities and civil societies in such arrangements, the case of the International Federation of Association Football (FIFA) provides strong evidence that global policies can be formulated and administered by completely private institutions relying on strong enforcement mechanisms and able to confront public authorities. FIFA's power results from its control of market access to global football, which represents a vital club good for national football industries. Therefore, FIFA is able to force European Union member states to deviate from national paths of sport regulation. Without orchestrating their efforts, public authorities are unlikely to succeed in challenging FIFA's power. Although the recent corruption scandals might force FIFA to implement some reforms, FIFA has a vital interest in protecting its regulatory powers.
\end{abstract}

Keywords: FIFA, Governance, Football, National governments, transnational regulation. 


\section{Introduction}

Football is not only a social phenomenon, but an expanding industry that is heavily controlled by the sport's governing body, the Fédération International de Football Association (FIFA). FIFA, a private not-for-profit association with headquarters in Switzerland, attributes to itself the powers to govern and regulate world football in collaboration with continental confederations and national football associations (FAs), from the rules of the game to the social and economic dimensions (FIFA 2015a, Articles 1-13).

At the moment, FIFA is engulfed in major scandals. An investigation led by the US and Swiss police authorities ended up with senior members of the governing body detained to be extradited to the United States, where they face accusation of alleged large-scale corruption, tax evasion and money laundering, among others (Gibson and Gayle 2015). Misconduct and corruption within FIFA have been denounced for a long time (Jennings 2006; Calvert and Blake 2014) and there have been numerous calls to increase FIFA's accountability towards stakeholders and public authorities (Lyons et al. 2014). After many years resisting calls for reform, FIFA president, Joseph Blatter, decided to lay down his position just days after being re-elected by the 2015 FIFA congress. However, Blatter announced that he will implement structural changes before an extraordinary congress elects his successor, to ensure an improved FIFA remains strong and independent (FIFA 2015b). Thus, even in the middle of its most important crisis in decades, FIFA has signaled its will to keep in control of the reform agenda.

While the corruption cases are outside of the scope of this paper, the way FIFA muddles through them raises the perplexity of the observer and lead to more general questions that form the core of this article: Why has FIFA successfully occupied a regulatory space that could have belonged to public authorities given the importance of football as a socio-economic activity? Furthermore, how is it possible that a private not-for-profit organization with headquarters in Switzerland is able to claim and maintain its autonomy from the so-called shadow of hierarchy of public authorities (Chappelet 2010)? 
Indeed, FIFA aims to 'control every type of association football' (FIFA 2012, Article 2, emphasis added). Here, we explore the different ways in which FIFA defends its autonomy to govern football privately in the global and transnational market, without the intervention of public authorities. It is necessary to clarify from the outset that we do not argue that FIFA has infinite powers in every situation; what the article does is to focus on the balance of forces of FIFA, as a private organization, vis-à-vis public authorities in the transnational regulation of football. Thus, on a theoretical level, FIFA is not just a case study for football enthusiasts as it reminds scholars to abandon 'methodological nationalism' and to realize that global policies can be formulated and administered by completely private institutions (Stone and Ladi 2015). Moreover, while scholars have focused on civil regulation employing soft law, FIFA illustrates that transnational private regulators can confront public authorities by relying on strong enforcement mechanisms.

The paper proceeds in four steps. First, we review the academic debates on transnational private regulation. Second, the paper examines why FIFA rose as a transnational private authority. It is argued that FIFA can impose its preferences on national governments because it controls access to global football as a 'club good' vital for national football industries. Third, as main empirical contribution the paper presents evidence of how FIFA exerted its power as transnational football regulator in three case studies against national governments of Greece, Spain and Poland. In the conclusion, we discuss the extent to which FIFA's multiple roles as regulator of the game, transnational corporation and grassroots movement can be contested by national governments on their own. We argue that due to football's character as grassroots movement, policy-makers at national level do not trust that the electorate will reward them for confronting FIFA. Accordingly, the present crisis might result in some organizational reforms, but FIFA is unlikely to waive its regulatory powers easily.

\section{Transnational private regulation}

Since Rosenau and Czempiel (1992) governance by non-state actors has increasingly occupied the attention of scholars (Mattli and Büthe 2005; Büthe 2010; Shamir 
2011). Private actors can participate in policy implementation (Pattberg 2005), transnational corporations (TNCs) provide public goods for failing states (Börzel and Risse 2010) or impose their demands on developing countries (Koenig-Archibugi 2004). Moreover, private actors are also engaged in transnational private regulation (TPR). Building on Pattberg (2005, p. 593) as well as Graz and Nölke (2007, p. 3), TPR can be defined as the ability of non-state actors to cooperate across borders in order to establish rules and standards of behavior in a distinct issue area accepted as legitimate by agents not involved in the rule definition. Thus, FIFA's regime can be conceptualized as a TPR since it establishes rules accepted by national FAs and governments. This raises the question of how private regulators claim power and how they exert it.

Scholars emphasizing the important role for TNCs in TPR claim that neoliberal ideology and the pursuit of corporate hegemony account for the rise of transnational private authority (Cutler et al. 1999; Johns 2007; Schäferhoff et al. 2009; Shamir 2011). More functionalist approaches argue that globalization has created a mismatch between markets and politics in terms of governance. Accordingly, demand for rules has given rise to a variety of sources of supply (Haufler 2000). Thus, private actors have assumed regulatory powers in order to deal with the necessities of global trade in the absence of international regulations by public authorities or effective intergovernmental regulatory action (Bartley 2007). In other words, they fill a regulatory vacuum of 'old international governance' (Abbott and Snidal 2009, p. 577; Schäferhoff et al. 2009; Bomhoff and Meuweuse 2011). The rise of private authority has also been framed as resulting from explicit or implicit delegation of certain functions by the state (Cutler et al. 1999).

Thus, there are diverging approaches to explaining and researching TPR. Vogel (2007, 2010) has distinguished two forms of TPR: (1) transnational industry self-regulation; and (2) 'civil regulation'. Traditional industry self-regulation has been depicted as serving to overcome collective action problems and to reduce transaction costs by specifying technical rules and guidelines for various materials, products and processes (Vogel 2007; Bartley 2007). In contrast, civil regulation specifies the responsibilities of global firms for addressing labor practices, environmental performance, and human rights policies (Vogel 2010, p. 68). According to Vogel (2010), civil regulation, intended to define standards for 
responsible business practices, is more likely to be politicized, transparent and to involve external stakeholders. In contrast, traditional industry self-regulation is depicted as intending to remove business regulation from public scrutiny. Given the diversity of industry self-regulation, which often anticipates public concerns (Gunningham and Reese 1997; Sinclair 1997; Black 2001) and an on-going debate about the rise of the regulatory state, which is supposed to rely on different forms of self-regulation (Levi-Faur 2014), Vogel's dichotomy appears reductionist. Thus, a central point made here is that, although global self-regulation is still under researched (Porter and Ronit 2006) scholars seem to have recently almost exclusively focused on civil regulation. While this interest in civil regulation has certainly generated new insights on TPR, it has also neglected some important phenomena.

First, research has emphasized the role of global civil society for the creation of civil regulations on global supply chains (Bartley 2007; Vogel 2010). Second, scholars have provided new (albeit diverging) answers concerning the relationship between private governance and public authority. On the one hand, scholars stressed that powerful non-state actors might challenge the authority of sovereign states (Sending and Neumann 2008). In particular, TNCs seem able to impose their rules on developing countries (Abbott and Snidal 2008, p. 538). Further, it is also argued that TPRs can depoliticize policy issues (Nölke and Perry 2007), which is likely to favor private actors over public authorities (Underhill and Zhang 2008). On the other hand, Börzel and Risse (2010, p. 116) claim that private governance is still subject to the 'shadow of hierarchy', that is, a credible threat of state intervention. Accordingly, the shadow of hierarchy catalyzes 'voluntary agreement[s] closer to the common good rather than to particularistic self-interests'.

Again, this dichotomous approach to TPR power seems slightly reductionist, given the complexities of current societies and economies. Pattberg and Stripple (2008; Falkner 2003) argue that the study of transnational civil regulations needs to go beyond the public-private divide since civil regulations represent business-civil society collaborations involving NGOs and multi-stakeholder organizations (Vogel 2007; Cafaggi 2011). Accordingly, Abbot and Snidal (2009) have suggested that civil regulations of transnational socio-economic activities are actually located in a governance triangle between public authorities, private firms and NGOs in which civil society or NGOs serve as ‘rule demanders' and supervisors (Overdevest 2010). 
Thus, the case of football (or sport) is of academic interest because FIFA acts as both, a TNC marketing global football and a civil society not-for-profit NGO.

Here, the crucial point is that the recent debate on civil regulation has depicted an image of TPR as practice that operates besides or around the state. The fact that there exist TPRs that can effectively establish rules modifying domestic policies against governments' will is neglected. Moreover, the focus on civil regulation has resulted in a narrow perspective on TPR enforcement. It is commonly assumed that firms participate in private regulation because the benefits of participation received exceed their costs (Lenox 2006). Potoski and Prakash (2005) argue that private regulation works because it provides specific 'club goods', that is, a non-rival but potentially excludable benefits. However, recent research on civil regulation has mainly dealt with 'soft law' mechanisms. Thus, the club good provided by civil regulations is mainly brand reputation, which is essential for TNCs (Vogel 2007).

Thus, two shortcomings of recent scholarship on TPRs are stressed. First, attention is called to the persistence of powerful transnational self-regulators able and willing to confront national governments. Transnational sport governance represents a long-established TPR, which originally filled a regulatory vacuum, able to selfregulate vis-à-vis public authorities and other third actors. Moreover, the case of FIFA provides evidence that powerful transnational industry self-regulation does not exclusively rely on 'naming and shaming'. In contrast, FIFA controls market access, which is vital club good for national football industries. The strong dependence of national industries on global market access allows transnational private regulators to impose their will on national governments. FIFA's claim for regulatory autonomy is exceptional in comparison with attempts to regulate global supply chains. However, FIFA's means of enforcement call for increased scholarly attention on the issue of TPR compliance.

\section{Governance and regulation in transnational football}

The governance of international football represents a mixture of a pyramid and a network of stakeholders, private commercial actors and public authorities (García 
2007). FIFA performs a three-fold role in the transnational governance of football: Regulation and rule making; fund raiser (through exploitation of the World Cup) and subsidizer (of national FAs that receive solidarity funds); and a market gate keeper because FIFA membership is a precondition for participation in international football competitions (FIFA 2015a). These governance capacities are exceptional even for international sport governing bodies (Forster 2006; Forster and Pope 2004). Thus, the International Olympic Committee (IOC) possesses certainly comparable 'global event power' (Rojek 2013) as FIFA but its governance covers only the Olympics (Chappelet and Kübler-Mabbott 2008). Other sport bodies lack FIFA's strong commercial powers posing the question why has risen FIFA to this level of regulatory capabilities without real noticeable opposition?

Research on FIFA's history suggests that FIFA's rise to power resulted from an institutional first-mover advantage and a complex interaction with the 'politicization of sport' (Tomlinson and Young 2006). Typically established as gentlemen's clubs (Tomlinson 2000) international sport governing bodies filled-in into a regulatory vacuum when they created and regulated international competitions, because national states did not address these matters then. Thus, the very creation of transnational sport governance contradicts ‘methodological nationalism’ (Stone and Ladi 2015). The acceptance of these sport bodies' claim for regulatory autonomy and the increasing participation of countries in their tournaments and competitions indicate some kind of 'implicit delegation' of a TPR regime. The very recent recognition by the United Nations (IOC 2014) and the European Union (article 165 of the Treaty on the Functioning of the European Union, in force since 2009) to support the so-called 'autonomy of sport', may be interpreted as a more explicit delegation of regulatory powers in favor of international sport governing bodies, such as FIFA.

Furthermore, FIFA increased this institutional first mover advantage when participating in international competitions came to equal being recognized as sovereign state in particular during decolonialization (Sugden and Tomlinson 1998; Darby 2005). Decolonialization also changed the composition of FIFA's constituency and its expectations concerning FIFA's role. The new (non-European) FIFA members pushed for an increase in World Cup places and financial and technical aid (Sugden and Tomlinson 1998). Moreover, these new members elected 
leaders to FIFA whose agenda was to commercialize the World Cup and to centralize FIFA's control over revenues, in order to share the increased income with the new developing football nations (Sugden and Tomlinson 1998; Murray 1999; Sugden 2002). As Jennings (2012) discussed for the IOC, massive commercialization inevitably required substantial adaptations in organizational governance. In the case of FIFA, commercialization served to strengthen its status as governing body as the increased revenues were used to grant substantial development aid to member FAs, which served to attract even more members (Eisenberg 2006a, 2006b). In return, the financial dependence of smaller FAs on FIFA's support heavily benefitted the power of the FIFA executive, and the role of FIFA as a governing body itself (Eisenberg 2006a; Giulianotti and Robertson 2012). With the exception of the international transfer system, these processes of expansion of FIFA, globalization and commercialization of the football industry developed with minimal intervention from governments and international organizations.

In result, FIFA claimed control of access to world football. Membership of FIFA is a necessary (pre)condition to participate in football's global competition structure, its revenue streams and regulation. Thus, FIFA membership provides access to 'club goods', which are vital for national football industries. Naturally, this provides FIFA with a privileged position. However, within the football industry, complex dependencies serve to limit FIFA's regulatory powers. For example, the regulation of clubs activities has generated tensions, especially in relation to transfers and release of players for international competition (see García and Meier 2012). As clubs employ players, FIFA had to adapt to demands from clubs about compensation (Conway 2015). Similarly, FIFA seems to be not always able to monitor its national or regional associations. This could be seen in the difficulties to implement antiracism policies or in Blatter's resignation speech where he blamed most of FIFA's problems on the excessive power of the continental confederations that had watered down his attempts for reform (FIFA 2015b). However, research presented here focuses on the relationship of FIFA with national governments.

In this context it is relevant that FIFA demands independence from any third parties as a pre-requisite for national FA's membership (FIFA 2012, Article 13.1g). In case football's autonomy is not respected in FIFA's eyes, the affected country may see their FA's membership suspended by the FIFA Executive Committee or the 
Congress (FIFA 2012, Article 14). A suspension excludes an FA (including clubs, referees, administrators, etc.) from the 'club goods' provided by FIFA and is, therefore, likely to severely damage the involved football economy.

In 2005 FIFA decided to implement a strategy to defend the autonomy of football over public authorities, hence solidifying its own position within the transnational regulatory regime. Moreover, FIFA seems determined to prevent the fragmentation of transnational policy implementation and administration, which scholars have noted in other global policy domains (Stone and Ladi 2015). Accordingly, the $55^{\text {th }}$ FIFA Congress legitimated the creation of a Task Force to address contemporary problems of football, among others 'the quest for autonomy by some leagues and political interference' (FIFA 2005a, b). FIFA demanded national governments to guarantee FAs' control over national leagues and even defined a deadline for legal adjustments:

'Nations with sport legislation in place that does not comply with the FIFA Statutes and especially where leagues are afforded a status whereby they are not subordinate to the football association (specifically, Greece, Poland and Portugal) shall have until 15 July 2006 to amend the relevant legislation.' (FIFA 2005a)

FIFA's Emergency Committee allows the body to quickly respond to noncompliance or political interference by suspending a country. In addition, the Associations Committee (AC) continuously monitors member FAs and public authorities where football's autonomy seems to at stake (FIFA 2008b). Whereas data on FIFA's monitoring activities are not fully accessible, FIFA considers them to be effective:

'[T]hrough monitoring, communication and reactivity, FIFA can try to prevent the emergence of a crisis. FIFA is a strong organization, not only in its football realm, but also in the political, socio-economical world, and we can and should use this strength to help our members.' (FIFA 2011)

As tracing the amount of FIFA's monitoring activities is difficult, our analysis focuses on formal suspensions. A ten year survey allows to infer that conflicts between FIFA, national FAs and governments occur quite often since FIFA imposed 24 suspensions over the last ten years. At least six FAs more have been threatened with suspension (Table 1$)^{1}$ 
'Governmental interference' represents by far the most important trigger for suspension. Reflecting FIFA's demand for far-reaching regulatory autonomy, the definition of 'governmental interference' is broad, including legislative acts adopted by parliaments as well as judicial actions against FAs or their officials. Moreover, suspensions seem to be effective. A very short period passes between a suspension and a lift. More importantly, the outcomes of the conflicts tend to be in line with FIFA's demands. While FIFA aims to involve all stakeholders, it insists on an uncompromized implementation of agreements that are in line with its own statutes.

Thus, an overview of the cases clearly demonstrates the powerful role of FIFA as a rule setter in this private transnational regulatory regime (i.e. football). However, regulatory compliance does not always equal effective implementation as 'repeat offenders', such as, Kenya and Greece, illustrate. In order to fully understand the dynamics of how FIFA enforces compliance vis-à-vis national governments, three in-depth case studies on FIFA's actions against 'governmental interference' are conducted.

\section{Enforcing regulation in international football: Three}

\section{case studies}

A case study approach is employed because it is particularly suited to investigate processes over a period of time (Yin 2014). More specifically, our research design represents a form of 'theory-testing process tracing' aiming to provide evidence that a certain causal mechanism is present (Beach and Pedersen 2013). In our case, the denial of club goods by FIFA is supposed to generate regulatory compliance. Thus, we deal with 'power in action' (Dahl 1957), which can be measured as the impcact of FIFA's intervention on the behavior of political actors.

As case study research collects evidence from a diversity of sources in order to arrive at relevant conclusions (Yin 2014), research presented is drawn from primary and secondary written sources: Official documents from FIFA, national FAs and national governments, as well as press reports and academic literature available. 
However, despite repeated attempts to contact FIFA and the relevant governments, not a single positive response was received. To some extent government turnover might account for these non-responses. We have mitigated this with the use of public documents, press releases and interviews in the press, which are used as a proxy of the official position of the institutions. Whereas this is indeed acknowledged up front as a limitation of the article, we have taken enough steps to minimize the impact on the validity of the analysis.

Greece, Spain and Poland were selected because they represent countries (a) where the rule of law is accepted and (b) where sport policy is made in a 'bureaucratic configuration' in which the sport bodies are supposed to act as agents for delivering government specified requirements and where they are accountable to the state (Henry and Ko 2009, pp. 30-5). Nevertheless, FIFA forced governments to deviate from these regulatory traditions. Moreover, the three cases vary in regard to the nature of governmental interference (formal application of state law in Spain, political rivalry in Greece, fight against corruption in Poland) and to the intensity of FIFA's intervention (purely informal threats: Spain, formal threats: Poland and formal suspension: Greece). For the sake of brevity, our presentation focuses on the nature of governmental interference and FIFA's intervention and regulatory outcomes (cf. Table 2, for detailed narratives see online appendix).

\section{***TABLE 2 ABOUT HERE***}

\section{Nature of governmental interference}

Greece. FIFA's conflicts with Greece have prolonged since 1990. The first conflicts were provoked by the Greek government's attempt to update governance structures in Greek football in response to commercialization and match fixing scandals. In 1993 the government proposed legislation to overhaul the nomination of referees and the composition of sport disciplinary courts in the Hellenic Football Federation (HFF) (Panagiotopoulos and Mourniakis 2006a, 2006b). After this attempt had failed, the Greek government again tried to tighten the regulatory framework for professional sport by proposing a new National Sports Act (Law 2725/1999). The 
law intended to give the state a greater oversight in governance structures (Dimitropoulos 2010; Panagiotopoulos and Mourniakis 2006a). In contrast, the 2006 conflict was triggered by the attempt of the newly elected conservative party New Democracy to assume control of the sport sector including the HFF (Anagnostopoulos 2011, pp. 212-3).

Spain. In contrast, in Spain the conflict arose over a minor technical detail of the Spanish Sports Act of 1990 (Law 10/1990), which includes very specific provisions regarding the governing structures of professional sport (García et al. 2011). The conflict had its origin in the regulation of the Spanish FA's (SFF) electoral process. In December 2007 the government adopted a ministerial order regulating elections in all sport federations:

'Elections will be made to coincide with the year of celebration of the Summer Olympic Games, and must start within the first quarter of this year. However, the Spanish sports federations that participate in the Summer Olympics shall begin their elections within two months from the end of the Olympic Games’ (Ministerial Order 2007, article 2).

With Spanish football not qualifying for the 2008 Olympics, the SFF was required to hold elections during the first trimester of 2008 (Expósito 2008a). However, the incumbent president proposed to organize the elections in the autumn implying noncompliance with the Ministerial Order. Although only involving a technical detail, the conflict was intensely covered by the Spanish press (Expósito 2008a, Mateo 2008a, b).

Poland. As corruption has been endemic within Polish football (Kędzior and Szczepanik 2011, Włoch 2013), the government tried twice to address this issue. The Polish minister of sport suspended the board of the Polish Football Association (PFA) and assumed interim management first in January 2007. After this intervention had failed, the government tried eighteen months later again to mitigate mismanagement and match fixing within the PFA (Włoch 2013). The government waited until UEFA had awarded Euro-2012 to Poland and intervened on 29 September 2008, just one day before candidates for the PFA board were to be 
nominated. In order to legitimize the intervention, the government had now asked the Polish National Olympic Committee to nominate a supervisor (Infotuba 2008).

\section{Nature of FIFA's intervention}

Greece. In all conflicts, FIFA became involved on request of the HFF, which did not accept the government's initiatives. In response, FIFA threatened to suspend the HFF in 1993 implying an exclusion from 1994 World Cup on grounds of excessive state intervention (Panagiotopoulos and Mourniakis 2006a). In a similar manner, FIFA threatened in 2001 to suspend the HFF 'from all international football activities' (FIFA 2001a), including the upcoming 2002 FIFA World Cup. FIFA demanded the Greek government on 19 March 2001 to 'immediately refrain from interfering with the affairs of the HFF':

'This undertaking has to be made by the Greek government not later than 30 March 2001. Furthermore, FIFA requests that the required provisions or amendments to Greek sports legislation should be carried out and be in place by 25 April 2001.' (FIFA 2001a)

However, in the 2006 conflict, the threat of suspension did not suffice. After the government had failed to comply with FIFA's deadline, HFF was suspended with immediate effect in July 2006 (FIFA 2006a). While the Greek sports minister insisted on the government's right to regulate football governance (BBC Sport 2006), the following social and political pressure to comply with FIFA's demands prompted the Prime Minister to intervene personally (Anagnostopoulos 2011, p. 214).

Spain. In the case Spanish case, informal threats sufficed. In February 2008, FIFA President Blatter travelled to Madrid to pay tribute to football legend Alfredo Di Stéfano. During a press conference, Blatter commented:

'This situation in Spain is incomprehensible. We fully support the federation and hope that the government understands the risk; FIFA's Emergency Committee could meet in just six hours by phone or electronically to suspend the federation’ (Mateo 2008a).

Blatter deemed the ministerial order an 'unacceptable intervention in football matters' and indicated possible consequences: 'It seems as if the Spanish government does not want its national team and its clubs to participate in international 
competitions' (Expósito 2008a). While the Spanish government signaled to take a strong stance (Expósito 2008b; El País 2008) and even suggested that administrative sanctions could be imposed upon the SFF (Suárez 2008a), the SFF decided to hold the presidential election in November that year (Carbajosa 2008; Ávila 2008). Blatter expressed his support:

'If [the Spanish government] take[s] any decision against the Spanish FA we will have to intervene, and I really do not want to do it. I hope that will not be the case' (quoted in Mateo 2008b).

Poland. Immediately after the Polish government had suspended the incumbent PFA board, UEFA and FIFA demanded the removal of the government's supervisors and threatened with suspension and denial of FIFA subsidies. FIFA demanded that the ‘internationally recognized administration' of the PFA should organize elections under the supervision of UEFA and FIFA (FIFA 2007). The government was also sent signals that Poland's candidature for Euro-2012 might not be considered (Kędzior and Szczepanik 2011, p. 211). In 2008, UEFA and FIFA also refused to recognize the supervisor (UEFA 2008). Furthermore, FIFA threatened Poland with exclusion from the 2010 World Cup and announced the cancellation of upcoming qualification matches (FIFA 2008). Initially, the Polish government was confident of convincing UEFA and FIFA that violations of the law by the PFA justified the measure (Infotuba 2008). However, FIFA did not accept these arguments (WPROST 2008). UEFA even threatened to withdraw Euro-2012 from Poland (Kędzior and Szczepanik 2011, p. 212). In a letter to the Polish Prime Minister, Donald Tusk, FIFA defined a clear deadline 'of Monday 6 October at noon' to remove the supervisor (FIFA 2008a).

\section{Regulatory outcomes}

Greece. After FIFA's first intervention, the government abandoned the proposed legislation (Panagiotopoulos and Mourniakis 2006a). In 2001, representatives of the Greek government and FIFA met in Zurich (FIFA 2001b) and agreed to reform the Greek Sports Act 'on basis of an action plan proposed by FIFA' (FIFA 2001b; 2001c). In result, the government watered down its initial proposals and left the HFF structures mostly unchanged (Panagiotopoulos and Mourniakis 2006a; 2006b). 
Finally, in 2006, just eight days after the suspension, the Greek parliament amended the National Sports Act:

'Specifically, for the sport of football, all the subjects of functioning and organisation of the sport, the Hellenic Football Federation and its members are self-governed by the HFF and its bodies, according to its statutes and regulations, as well as those that are determined by the Union des Associations Européennes de Football (UEFA) and the Fédération Internationale de Football Association (FIFA), even if different regulations are provided in the law 2725/1999, as it is in effect in the athletic legislation.' (FIFA 2006b, emphasis added)

Satisfied with this opt-out granted only for football, FIFA lifted the suspension (FIFA 2006b).

Spain. Despite much talk through the press, there were no formal proceedings opened by FIFA against Spain. Eventually, the elections took place on 24 November 2008, the preferred solution of the SFF and FIFA (Suárez 2008c). The government was surprisingly at ease with that decision (González-Martín 2008). There are suggestions of a 'diplomatic pact' between the SFF President and the Secretary of State for Sport (Suárez 2008b). Formally, the SFF presented a written submission to the government in April 2008, simply informing about the decision to hold elections in November (Iríbar 2008).

Poland. Facing the threat of suspension and of being not awarded the Euro-2012 the Polish government swiftly removed its supervisor (Kędzior and Szczepanik 2011, p. 211). Meeting fierce resistance by FIFA and UEFA once more, the government agreed to remove the supervisor once the independent election committee of the PFA (with participation of the Sport Ministry, FIFA and UEFA) had started preparing new elections. While the old PFA board had to admit some misconduct, the new elected board tried to suspend all further investigation into corruption within Polish football in June 2009. Although the PFA's general assembly voted the proposal down, the PFA's stance towards corruption remains questionable (Kędzior and Szczepanik 2011, p. 212). 


\section{Discussion and conclusion}

Research presented here has explored the extent to which transnational industry selfregulation persists as a form of TPR able to challenge attempts by national governments to set rules in the sector. The cases show that FIFA is able to confront national governments and defend its autonomy to regulate football. Suspensions (or the threat of them) serve as an efficient means to enforce compliance of national FAs and public authorities. Governments even modify their sport policy and legislation once FIFA formally or informally requested so. FIFA even defined deadlines for governments to comply and devised road maps for conflict resolution. In Greece, FIFA obtained a regulatory exemption for football; in Spain, the government preferred to avoid conflict; in Poland, the government had to accept a relatively lenient stand towards corruption and match fixing. Looking through the list of the last ten years provided above, there is not a single case where national governments decided to confront, face on, FIFA. In sum, FIFA seems to support claims about the undermining effects of private power on legitimate public authority. For scholars of global policy, FIFA serves as reminder to abandon 'methodological nationalism' and to perceive states as dependent rather than independent variable in global policy making (Stone and Ladi 2015).

FIFA's power over national football industries and policy-makers seems to result from the fact that FIFA provides national football industries an exclusive and vital 'club good', that is, in participation in global football. Failure to comply means that national football industries are excluded from international football, FIFA subsidies and protection against player mobility. Thus, FIFA can effectively control access to a market, which is essential for the economic viability of national football industries. FIFA's regulatory ambitions probably reflect football's massive commercialization setting strong incentive for the governing body to maintain concentrated control over international football and its revenues.

For scholars of TPR the case of FIFA serves first as reminder that despite scholarly focus on civil regulation, powerful transnational industry self-regulation persists relying on hard enforcement mechanisms. Once transnational private regulators occupy such a powerful position, they are not only able to eclipse the shadow of hierarchy but also to challenge national regulations if global market 
access is vital for national industries. Accordingly, in contrast to the recent scholarly focus on civil regulation, future research should pay attention to more diverse forms of TPR, their enforcement mechanisms and impact on domestic policies. As indicated above, although transnational sport regulation represents a long-standing and influential TPR it has slipped academic attention for long.

As demonstrated, FIFA's enforcement mechanism allows national FAs to initiate a two-level game. FAs are able to invoke FIFA's intervention against national governments. In order to understand why national governments comply it is necessary to take the preferences of political stakeholders into account. Besides professional football's economic impact, it seems that FIFA benefits from football's global popularity and the political meaning ascribed to it. After being codified in British elite schools in the $19^{\text {th }}$ century, football enjoyed an unprecedented global migration and popularity (Giulianotti 1999). Moreover, FIFA benefits from the general politicization of international sports (Tomlinson and Young 2006). The modern Olympics became quite early a vehicle for national representation though sports (Krüger 1995), then for cold war politics (Allison and Monnington 2002) as well as for decolonialization (Sugden and Tomlinson 1998; Darby 2005). Given the importance of sport for national identity politics, it seems safe to consider that suspension from a national team competition may not be well received by public opinion. Here, it is useful to recall the history of Sevilla FC and Celta de Vigo in Spain in 1995 (El Pais 1995). Administrative decisions relegated both clubs to play non-league football due to insolvency, which triggered public demonstrations of more than 250,000 people and finally resulted in a withdrawal of the decision.

Hence, whereas consumer campaigns account for transnational civil regulation, it seems that FIFA benefits from a lack of societal corrective forces. Quite the opposite, FIFA presides over a large grassroots movement, acting also as a notfor-profit NGO in football's transnational regime when it suits. Therefore, national governments seem to be willing to avoid conflicts with FIFA in order not to test the consequences of their policies in their voters at the cost of a suspension. This, in turn, can explain why FAs can escalate conflicts by involving FIFA.

Seen in the light of both current scandals and the debate about TPRs, the case of FIFA raises the more general question to what extent TPRs can escape becoming politicized. Our findings do not necessarily imply that governments cannot challenge 
the power of FIFA at all, but that it takes a lot of 'courage' for them to do so. So far the European Union is probably the only governmental organisation that has been able to exert some form of authority over football authorities. The EU requested that FIFA amends its international transfer system to some extent (García 2011) and forced UEFA to negotiate over the selling of broadcasting rights (García 2008). Yet, these interventions were controversial among the member states allowing the football bodies to reap substantial concessions from the initial EU demands (Meier and García 2012).

The debates about 2014 World Cup already signaled an increased contestation of FIFA's power. The recent escalation of FIFA's legitimacy crisis indicates that this TPR can become politicized with conflicting demands. However, it should be realized that it has taken years of very serious allegations and criminal investigations before police authorities decided to act. At this moment, dissatisfaction with FIFA's governance seems to have reached a point where a broad coalition of stakeholders pushes for reform. However, the ability of FIFA to 'resist' as a powerful TPR should not be underestimated even under the present circumstances. Here, it is useful to consider the IOC's Salt Lake City-corruption scandal (Mallon 2000; Hamilton 2010). After it was revealed that several IOC members had been bribed, the IOC President had even to testify before the U.S. Congress. The scandal catalyzed an impressive number of institutional changes. Thus, the IOC defined age and term limits for its member, created four categories of members in order to increase democratic accountability, reformed the bidding procedures and improved financial transparency (cf. Mallon 2000; Wenn and Martyn 2006). However, these changes did not affect the IOC's demand for regulatory autonomy, revenue maximization and control of the IOC's commercial assets. In other words, despite some changes and opening, the IOC is still recognized as the sole authority of the Olympic movement. Therefore, the recent scandal might force FIFA to reform its corporate governance in a similar manner. However, it should not be expected that FIFA is likely to waive regulatory powers vis-à-vis FAs and governments as a broad coalition within FIFA pursues revenue maximization. 


\section{Notes}

1 Cambodia, Hungary, Indonesia, Kazakhstan, Macedonia and Venezuela.

\section{Acknowledgments}

The authors are grateful for the constructive comments provided by four anonymous reviewers and the editor, which helped to substantially improve the paper. Moreover, the authors would like to thank Ian Henry and Mark Pollack for comments on earlier drafts. Finally, the authors are indebted to Kathrin Czichon for translating Polish sources.

\section{References}

Abbott, K.W. and D. Snidal. 2009. 'Strengthening International Regulation through Transnational New Governance: Overcoming the Orchestration Deficit', Vanderbilt Journal of Transnational Law, 42, 2, 501-78.

Allison, L. and T. Monnington. 2002. 'Sport, Prestige and International Relations', Government and Opposition, 12, 1, 106-134.

Anagnostopoulos, C. 2011. 'The Battlefield of Greek Football: Organising top-tier Football in Greece', in H. Gammelsaeter and B. Senaux (eds), The Organisation and Governance of Top Football Across Europe. Abingdon: Routledge, pp. 207-23.

Ávila, J. 2008. 'La Asamblea saca al fútbol de la ley', ABC, 4 March 2008, 35.

Bartley, T. 2007. 'Institutional Emergence in an Era of Globalization: The Rise of Transnational Private Regulation of Labor and Environmental Conditions', American Journal of Sociology, 113, 297-351.

BBC Sport. 2006. 'Greece given suspension by FIFA.' BBC Sport, 4 July 2006, available at http://news.bbc.co.uk/sport1/hi/football/internationals/5141866.stm (accessed 29 May 2014).

Beach, D. and R.B. Pedersen. 2013. Process-Tracing Methods. Foundations and Guidelines, Michigan: The University of Michigan Press.

Black, J. 2001. 'Decentring regulation: Understanding the role of regulation and self-regulation in 'post-regulatory' world', Current Legal Problems, 54, 103-46.

Bomhoff, J. and A. Meuwese. 2011. 'The Meta-regulation of Transnational Private Regulation', Journal of Law and Society, 38, 1, 138-62.

Börzel, T. and T. Risse. 2010. 'Governance without a State: Can it work?', Regulation and Governance, 4, 1, 113-34.

Büthe, T. 2010. 'Private Regulation in the Global Economy: A (P)Review', Business and Politics 12, DOI: 10.2202/1469-3569.1328.

Cafaggi, F. 2011. 'New Foundations of Transnational Private Regulation', Journal of Law and Society, 38, 1, 20-49.

Calvert, J. and H. Blake. 2014. 'Plot to buy the World Cup', The Sunday Times, $1^{\text {st }}$ June 2014.

Available online at

http://www.thesundaytimes.co.uk/sto/news/uk_news/fifa/article1417325.ece (accessed 25 February 2015).

Carbajosa, C.E. 2008. 'El fútbol desafía al gobierno', El Mundo, 4 March 2001, 51.

Chappelet, J.-L. 2010. Autonomy of Sport in Europe. Strasbourg: Council of Europe.

Chappelet, J.-L. and B. Kübler-Mabbott. 2008. The International Olympic Committee and the Olympic System. The governance of world sport. London: Taylor \& Francis Ltd.

Conway, R. 2015. 'World Cup: Clubs to receive £142m for releasing players', BBC Sport, 20 March 2015, available at http://www.bbc.co.uk/sport/0/football/31984954 (accessed 2 June 2015). 
Cutler, A.C., V. Haufler and T. Porter. 1999. Private Authority and International Affairs. New York: Suny Press.

Dahl, R.A. 1957. 'The concept of power', Behavioral Science, 2, 3, 201-15.

Darby, P. 2005. 'Africa and the "World” Cup: FIFA Politics, Eurocentrism and Resistance', International Journal of the History of Sport, 22, 5, 883-905.

Dimitropoulos, P. 2010. 'The Financial Performance of Greek Football Clubs', Choregia Sport Management International Journal, 6, 1, 5-28.

Eisenberg, C. 2006a. 'Der Weltfußballverband FIFA im 20. Jahrhundert. Metamorphosen eines "Prinzipienreiters"', Vierteljahrshefte für Zeitgeschichte, 54, 209-30.

Eisenberg, C. 2006b, 'FIFA 1975-2000: the Business of a Football Development Organisation', Historical Social Research/Historische Sozialforschung, 31, 1, 55-68.

El País (1995) 'Sevilla y Celta bajan a Segunda B', El País, 2nd August 1995, available at: http://elpais.com/diario/1995/08/02/deportes/807314413_850215.html (accessed 1 July 2015).

El País. 2008. 'Zapatero: La Federación de be cumplir la ley.’ El País, 7 March 2008, 71.

Expósito, J. 2008a. 'FIFA amenaza: Blatter advierte que la selección y los equipos de España pueden ser vetados si se adelantan las elecciones en la federación', El Mundo, 18 February 2008, 5.

Expósito, J. 2008b. 'Lissavetzky responde a Blatter', El Mundo, 19 February 2008, 51.

Falkner, R. 2003. 'Private Environmental Governance and International Relations: Exploring the Links', Global Environmental Politics, 3, 2, 72-87.

FIFA (Fédération Internationale de Football Association). 2001a. 'FIFA asks Greek Government to Refrain from Interfering with Football.' Media release, 20 March 2001. Available at http://www.fifa.com/newscentre/news/newsid=76935/ (accessed 28 May 2014).

FIFA. 2001b. 'Suspension of Greek FA averted after signature of joint declaration.' Media release, 30 April 2001. Available online at http://www.fifa.com/newscentre/news/newsid=77442/index.html (accessed 28 May 2014).

FIFA. 2001c. 'FIFA, Greek FA and Greek government sign agreement to normalize situation.' Media release, 2 August 2001. Available online at http://www.fifa.com/newscentre/news/newsid=78798/ (accessed 28 May 2014).

FIFA (Fédération Internationale de Football Association). 2005a. 'FIFA Task Force to tackle current Football Problems.' Media release, 10 September 2005. Available online at http://www.fifa.com/aboutfifa/organisation/news/newsid=100056/ (accessed 28 May 2014).

FIFA (Fédération Internationale de Football Association). 2005b. 'Green light for the FIFA Task Force - Timor-Leste and Comoros join FIFA Family.’ Media Info, 12 September 2005.

FIFA (Fédération Internationale de Football Association). 2006a. 'FIFA suspends the Hellenic Football Federation.' Media release, 3 July 2006. Available online at http://www.fifa.com/worldfootball/releases/newsid=104401.html (accessed 28 May 2014).

FIFA (Fédération Internationale de Football Association). 2006b. 'FIFA lifts suspension on Hellenic Football Federation.' Media release, 12 July 2006. Available online at http://www.fifa.com/worldfootball/releases/newsid=104439.html (accessed 28 May 2014).

FIFA (Fédération Internationale de Football Association). 2007. 'Poland and Kenya warned about Governmental Interference.' Media Information, January 31, 2007. Available online at http://www.fifa.com/aboutfifa/organisation/news/newsid=110859/index.html $\quad$ (accessed 28 May 2014).

FIFA (Fédération Internationale de Football Association). 2008a. 'FIFA letter sets Poland Deadline.' October 2008. 2, Available online at http://www.fifa.com/aboutfifa/organisation/administration/news/newsid=895709/index.html. (accessed 28 May 2014).

FIFA (Fédération Internationale de Football Association). 2008b. 'Strong defence of the independence of football associations.' Media Info, 6 February 2008.

FIFA (Fédération Internationale de Football Association). 2011. 'Regenass: We have strong Principles.' $\quad$ FIFA.com, 19 October 2011. Available online at http://www.fifa.com/aboutfifa/news/newsid=1528544/index.html (accessed 28 May 2014).

FIFA (Fédération Internationale de Football Association). 2012. FIFA Statutes July 2012 Edition. Zurich: FIFA.

FIFA. 2014. 'FIFA World Cup group stages break new ground in TV viewing', FIFA Media Release, 28 June 2014. Available online at http://www.fifa.com/worldcup/news/y=2014/m=6/news=fifa-world-cuptm-group-stages-breaknew-ground-in-tv-viewing-2388418.html (accessed 25 February 2015).

FIFA. 2015a. FIFA Statutes April 2015 Edition. Zurich: FIFA. 
FIFA. 2015b. 'FIFA President to lay down his mandate at extraordinary elective Congress', FIFA.com, 2 June 2015.2 Available at http://www.fifa.com/governance/news/y=2015/m=6/news=fifa-president-to-lay-down-hismandate-at-extraordinary-elective-congr2617742.html?intcmp=fifacom_hp_module_news_top (accessed 2 June 2015).

Forster, J. 2006. 'Global sports organisations and their governance', Corporate Governance, 6, 1, 7283.

Forster, J. and N. Pope. 2004. The political economy of global sporting organisations. London-New York: Routledge.

García, B. 2007. 'UEFA and the European Union, from Confrontation to Co-operation?', Journal of Contemporary European Research, 3, 3, 202-23.

García, B. 2008. The European Union and the governance of football: a game of levels and agendas. Loughborough: Borja García García.

García, B. 2011. 'The 2001 informal Agreement on the International Transfer System', European Sports Law and Policy Bulletin, 1/2011, 13-25.

García, B., A. Palomar and C. Pérez. 2011. 'Spain: Parochialism or Innovation?', in: A. Niemann, B. García and W. Grant (eds), The Transformation of European Football: Towards the Europeanisation of the National Game. Manchester: Manchester University Press, pp. 134151.

Garcia, B. and H.E. Meier (2012). 'Abandoning hopes for veto power: institutional options for sport governing bodies in the European Union', International Journal of Sport Policy and Politics, DOI:10.1080/19406940.2012.656678.

Gibson, O. and D. Gayle. 2015. 'Fifa officials arrested on corruption charges as World Cup inquiry launched', The Guardian, $27^{\text {th }}$ May 2015. Available online at: http://www.theguardian.com/football/2015/may/27/several-top-fifa-officials-arrested (accessed 28 May 2015).

Giulianotti, R. 1999. Football: A Sociology of the Global Game. Cambridge: Polity.

Giulianotti, R. and R. Robertson. 2012. 'Mapping the global football field: a sociological model of transnational forces within the world game', British Journal of Sociology, 63, 2, 216-40.

González-Martín, T. 2008. 'Lissavetzky: El retraso de las elecciones de la FEF cumple la le', ABC, 25 April 2008, 47.

Graz, J.-C. and A. Nölke. 2007. 'The Limits of Transnational Private Governance.' Paper prepared for EAEPE Conference 2007, 1-3 November 2007, Porto, Portugal.

Gunningham, N. and J. Rees. 1997. 'Industry self-regulation: An institutional perspective', Law and Policy, 19, 4, 363-414.

Hamilton, T.A. 2010. 'The Long Hard Fall from Mount Olympus: The 2002 Salt Lake City Olympic Games Bribery Scandal', Marquette Sports Law Review, 21, 1, 219-40.

Haufler, V. 2000. 'Private sector international regimes', in: R. Higgott, G. Underhill and A. Bieler, (eds), Non-State Actors and Authority in the Global System. New York: Routledge, pp. 121137.

Henry, I. and L.-M. Ko. 2009. 'European Models of Sport: Governance, Organisational Change and Sports Policy in the EU', in: W. Tokarski and K. Petry (eds), Handbuch Sportpolitik. Schondorf: Hofmann, pp. 25-47.

Infotuba. 2008. 'Bezpieczne porządki w PZPN?' Infotuba, 30 September 2008. Available online at http://www.infotuba.pl/sport/bezpieczne_porzadki_w_pzpn_a3360.xml (accessed 29 May 2014).

IOC (International Olympic Committee). 2014. 'Historic milestone: United Nations recognises autonomy of sport', Olympics.org, 13 December 2014, available at http://www.olympic.org/news/historic-milestone-united-nations-recognises-autonomy-ofsport/240276 (accessed 2 June 2015).

Iríbar, A. 2008. 'Villar se sale con la suya', El País, 23 April 2008, 71.

Jennings, A. 2006. Foul! The secret world of FIFA: Bribes, vote rigging and ticket scandals. London: Harper Sport.

Jennings, A. 2011.'Investigating corruption in corporate sport: The IOC and FIFA', International Review for the Sociology of Sport, 46, 4, 387-98.

Jennings, W. 2012. Olympic Risks. London: Palgrave Macmillan.

Johns, F. 2007. 'Performing Power: The Deal, Corporate Rule, and the Constitution of Global Legal Order', Journal of Law and Society, 34, 1, 116-38. 
Kędzior M. and M. Szczepanik. 2011. 'Poland: New Shape, Old Problems', in: A. Niemann, B. García, and W. Grant (eds), The Transformation of European Football: Towards the Europeanisation of the National Game. Manchester: Manchester University Press, pp. 204-19.

Koenig-Archibugi, M. 2004. 'Transnational Corporations and Public Accountability', Government and Opposition, 39, 2. 234-259.

Krüger, A. 1995. "Buying victories is positively degrading” European origins of government pursuit of national prestige through sport', International Journal of the History of Sport, 12, 2, 183-200.

Lenox, M.J. 2006. 'The role of private decentralized institutions in sustaining industry self-regulation', Organization Science, 17, 6, 677-90.

Levi-Faur, D. 2014. 'The welfare state: A regulatory perspective', Public Administration, 92, 3, 599614.

Lyons, J., A. Lines and J. Blanchard. 2014. 'David Cameron: Fifa members lied to David Beckham, Prince William and I over World Cup bid', Daily Mirror, 2 June 2014, available online at http://www.mirror.co.uk/sport/football/news/david-cameron-fifa-members-lied-3638640 (accessed 25 February 2015).

Mallon, B. 2000. 'The Olympic Bribery Scandal', Journal of Olympic History, 8, 2, 11-27.

Mateo, J.J. 2008a. 'Blatter: El gobierno debe comprender el riesgo que corre', El País, 18 February 2008, 65.

Mateo, J.J. 2008b. 'Blatter: El Gobierno español debe dejar de ejercer presión', El País, 15 March 2008, 55.

Mattli, W. and T. Büthe. 2005. 'Global Private Governance: Lessons from a National Model of Setting Standards in Accounting', Law and Contemporary Problems, 68, 3/4, 225-62.

Murray, B. 1999. 'FIFA', in J. Riordan and A. Krüger (eds), The International Politics of Sport in the Twentieth Century. London-New York: E \& FN SPON, pp. 28-47.

Nölke, A. and J. Perry. 2007. 'The Power of Transnational Private Governance: Financialization and the IASB', Business and politics, 9, 3, 1-25.

Overdevest, C. 2010. 'Comparing Forest Certification Schemes: The Case of Ratcheting Standards in the Forest Sector', Socio-Economic Review, 8, 1, 47-76.

Panagiotopoulos, D. and I. Mourniakis. 2006a. 'Suspension of Governing Bodies: Analysis', World Sport Law Report, 4, 7, 8-11.

Panagiotopoulos D. and I. Mourniakis. 2006b. 'Verbandsautonomie und staatliche Regulierung - Der Konflikt zwischen FIFA und Griechischem Fußballbund', Sport und Recht, 13, 5, 190-192.

Pattberg, P. and J. Stripple. 2008. 'Beyond the Public and Private Divide: Remapping Transnational Climate Governance in the 21st century', International Environmental Agreements, 8, 4, 36788.

Pattberg, P. 2005. 'The Institutionalization of Private Governance: How Business and Nonprofit Organizations agree on Transnational Rules', Governance, 18, 4, 589-610.

Porter, T. and K. Ronit. 2006. 'Self-Regulation as Policy Process: The Multiple and Criss-Crossing Stages of Private Rule-Making', Policy Sciences, 39, 1, 41-72.

Potoski, M. and A. Prakash. 2005. 'Green Clubs and Voluntary Governance: ISO 14001 and Firms' Regulatory Compliance', American Journal of Political Science, 49, 2, 235-48.

Rojek, C. 2013. Event Power: How Global Events Manage and Manipulate. London: Sage.

Rosenau, J. and E.-O. Czempiel. 1992. Governance without Government: Order and Change in World Politics. Cambridge: Cambridge University Press.

Schäferhoff, M., S. Campe and C. Kaan. 2009. 'Transnational Public-Private Partnerships in International Relations: Making Sense of Concepts, Research Frameworks, and Results', International Studies Review, 11, 3, 451-74.

Sending, O.J. and I.B. Neumann. 2006. 'Governance to Governmentality: Analyzing NGOs, States, and Power', International Studies Quarterly, 50, 3, 651-72.

Shamir, R. 2011. 'Socially Responsible Private Regulation: World Culture or World-Capitalism?', Law and Society Review, 45, 2, 313-36.

Sinclair, D. 1997. 'Self-regulation versus command and control? Beyond false dichotomies.', Law and Policy 19, 4, 529-59.

Stone, D. and S. Ladi (2015). 'Global Public Policy and Transnational Administration', Public Administration.

Suárez, O. 2008a. 'La solución al conflicto entre Villar y Lissavetzky se complica', El Mundo, 26 March 2008, 46.

Suárez, O. 2008b. 'Pacto “semantic” Villar-Lissavetzky: El acuerdo final pendiente de un trámite', El Mundo, 1 April 2008, 48. 
Suárez, O. 2008c. 'Villar, eterno: El presidente de la federación es reelegido sin votos en contra', El Mundo, 25 November 2008, 46.

Sugden, J. 2002. 'Network football', in J. Sugden and A. Tomlinson (eds), Power Games: A critial Sociology of Sport. London: Routledge, pp. 61-80.

Sugden, J. and A. Tomlinson. 1998. 'Power and Resistance in the Governance of World Football: Theorizing FIFA's transnational Impact', Journal of Sport and Social Issues 22, 3, 299-316.

Tomlinson, A. 2000. 'FIFA and the men who made it', Soccer and society, 1, 1, 55-71.

Tomlinson, A. and C. Young (eds). 2006. National identity and global sports events: Culture, politics, and spectacle in the Olympics and the football World Cup. New York: Suny Press.

UEFA (Union of European Football Associations). 2008. 'UEFA and FIFA did not recognize Nomination of “Administrator” of the Polish FA. Media Release, September 20, 2008.' Available online at http://www.uefa.com/uefa/mediaservices/mediareleases/newsid=942119.html $\quad$ (accessed 29 May 2014).

Underhill, G.R.D. and X. Zhang. 2008. 'Setting the rules. Private power, political underpinnings, and legitimacy in global monetary and financial governance', International Affairs, 84, 3, 535-54.

Vogel, D. 2007. 'Private Global Business Regulation', Annual Reviews of Political Science, 11, 26182.

Vogel, D. 2010. 'The private regulation of global corporate conduct: Achievements and limitations', Business and Society, 49, 1, 68-87.

Wenn, S.R. and S.G. Martyn. 2006. 'Tough Love: Richard Pound, David D'Alessandro, and the Salt Lake City Olympics Bid Scandal', Sport in History, 26, 1, 64-90.

Włoch, R. 2013. 'UEFA as a New Agent of Global Governance: A Case Study of Relations between UEFA and the Polish Government against the Background of the UEFA EURO 2012', Journal of Sport and Social Issues, 37, 3, 297-311.

WPROST. 2008. 'FIFA nie zmiena stanowiska.' WPROST, 3 October 2008. http://www.wprost.pl/ar/140407/FIFA-nie-zmienia-stanowiska/ (accessed 29 May 2014).

Yin, R. 2014. Case study research: Design and methods, 5th edn. Los Angeles: Sage. 
TABLE 1 FIFA's suspension of member FAs 2003 - 2013

\begin{tabular}{|c|c|c|c|c|}
\hline Member FA & $\begin{array}{l}\text { Date of } \\
\text { suspen- } \\
\text { sion } \\
\end{array}$ & Date of lift & Trigger of suspension & Outcome of FIFA intervention \\
\hline Azerbaijan & 15-Apr-03 & 23-May-03 & $\begin{array}{l}\text { External pressure, violations of } \\
\text { fundamental principles }\end{array}$ & $\begin{array}{l}\text { Parties agreed to respect a FIFA } \\
\text { moderated agreement }\end{array}$ \\
\hline $\begin{array}{l}\text { Antigua and } \\
\text { Barbuda }\end{array}$ & 20-May-03 & 29-Jun-05 & Non-specifed & $\begin{array}{l}\text { Suspension lifted after situation } \\
\text { had improved }\end{array}$ \\
\hline Guatemala & 9-Jan-04 & 17-May-04 & $\begin{array}{l}\text { Governmental interference: FA } \\
\text { and elected FA officials replaced }\end{array}$ & $\begin{array}{l}\text { Re-installment of elected FA } \\
\text { leadership, recognition of FAs' } \\
\text { competencies }\end{array}$ \\
\hline Kenya & 2-Jun-04 & 6-Aug-04 & $\begin{array}{l}\text { Governmental interference: FA } \\
\text { officials replaced due to } \\
\text { mismanagement and fraud }\end{array}$ & $\begin{array}{l}\text { Installment of a normalization } \\
\text { committee to improve } \\
\text { transparency and accountability }\end{array}$ \\
\hline Macau & 15-Feb-05 & 6-Mar-05 & $\begin{array}{l}\text { Governmental interference: } \\
\text { Non-specified }\end{array}$ & $\begin{array}{l}\text { Suspension lifted after } \\
\text { negotiations }\end{array}$ \\
\hline Yemen & 12-Aug-05 & 9-Nov-05 & $\begin{array}{l}\text { Governmental interference: } \\
\text { Non-specified }\end{array}$ & $\begin{array}{l}\text { Suspension lifted after } \\
\text { concessions by the government }\end{array}$ \\
\hline Greece & 3-Jul-06 & 12-Jul-06 & $\begin{array}{l}\text { Governmental interference: } \\
\text { National legislation granting } \\
\text { professional league independence } \\
\text { from FA was not revoked }\end{array}$ & $\begin{array}{l}\text { Legislation amended according to } \\
\text { FIFA's demands }\end{array}$ \\
\hline Kenya & 25-Oct-06 & 9-Mar-07 & $\begin{array}{l}\text { Governmental interference: } \\
\text { Non-implementation of } \\
\text { agreements, escalation of internal } \\
\text { conflicts }\end{array}$ & $\begin{array}{l}\text { Government declares to abstain } \\
\text { from further intervention, legal } \\
\text { proceedings are withdrawn, } \\
\text { reinstallation of elected officials }\end{array}$ \\
\hline Iran & 23-Nov-06 & 20-Dec-06 & $\begin{array}{l}\text { Governmental interference: } \\
\text { Non-independence of decision- } \\
\text { making and election processes }\end{array}$ & $\begin{array}{l}\text { Implementation of FIFA's } \\
\text { demands }\end{array}$ \\
\hline Kuwait & 29-Oct-07 & 20-Dec-08 & $\begin{array}{l}\text { Governmental interference: FA } \\
\text { officials replaced }\end{array}$ & $\begin{array}{l}\text { Suspension provisionally lifted } \\
\text { after new elections are } \\
\text { announced, reinstallation of } \\
\text { FIFA's transition committee, } \\
\text { amendment of FA's statutes }\end{array}$ \\
\hline Albania & 14-Mar-08 & 26-Apr-08 & $\begin{array}{l}\text { Governmental interference: } \\
\text { Government initiated legal } \\
\text { proceedings against new FA } \\
\text { statutes }\end{array}$ & $\begin{array}{l}\text { Legal proceedings stopped, } \\
\text { creation of a working-group }\end{array}$ \\
\hline Madagascar & 19-Mar-08 & 19-Мay-08 & $\begin{array}{l}\text { Governmental interference: } \\
\text { Ministerial decree dissolved FA }\end{array}$ & $\begin{array}{l}\text { Madagascan Supreme Court } \\
\text { declared decree null and void, re- } \\
\text { installment of FA }\end{array}$ \\
\hline Chad & 28-Mar-08 & 7-May-08 & $\begin{array}{l}\text { Governmental interference: } \\
\text { Government replaced FA officials } \\
\text { and intended to hold new } \\
\text { elections }\end{array}$ & $\begin{array}{l}\text { Decree revoked, reinstallation of } \\
\text { elected FA officials }\end{array}$ \\
\hline Iraq & 26-May-08 & 29-May-08 & $\begin{array}{l}\text { Governmental interference: } \\
\text { Governmental decree dissolved } \\
\text { all sport organizations }\end{array}$ & $\begin{array}{l}\text { Exclusion of FA from dissolution } \\
\text { decree }\end{array}$ \\
\hline Ethiopia & 29-Jul-08 & Unknown & $\begin{array}{l}\text { Governmental interference: } \\
\text { Dismissal of elected officials, } \\
\text { non-compliance with FIFA } \\
\text { roadmap }\end{array}$ & Unknown \\
\hline Samoa & 24-Oct-08 & 20-Dec-08 & Repeated management problems & Unknown \\
\hline Peru & 25-Nov-08 & 20-Dec-08 & $\begin{array}{l}\text { Governmental interference: } \\
\text { Non-specified }\end{array}$ & Unknown \\
\hline $\begin{array}{l}\text { Brunei } \\
\text { Darussalam }\end{array}$ & 29-Sep-09 & 1-Jun-11 & $\begin{array}{l}\text { Governmental interference: } \\
\text { Dissolution of FA and creation of }\end{array}$ & $\begin{array}{l}\text { FIFA's conditions fulfilled and } \\
\text { statues amended according to }\end{array}$ \\
\hline
\end{tabular}




\begin{tabular}{|c|c|c|c|c|}
\hline & & & new government controlled body & FIFA Statutes \\
\hline Iraq & 20-Nov-09 & 19-Mar-10 & $\begin{array}{l}\text { Governmental interference: } \\
\text { Government controlled NOC } \\
\text { dissolved FA }\end{array}$ & Dissolution of FA withdrawn \\
\hline El Salvador & 11-May-10 & 27-May-10 & $\begin{array}{l}\text { Governmental interference: } \\
\text { Government did not accept } \\
\text { FIFA's normalization committee } \\
\text { and new FA statutes }\end{array}$ & $\begin{array}{l}\text { Legitimacy of normalization } \\
\text { committee and new statutes } \\
\text { recognized }\end{array}$ \\
\hline Nigeria & 4-Oct-10 & 8-Oct-10 & $\begin{array}{l}\text { Governmental interference: } \\
\text { Court actions against FA officials, } \\
\text { governmentally forced resignation } \\
\text { of officials, government started } \\
\text { league without relegation from } \\
\text { previous season }\end{array}$ & $\begin{array}{l}\text { Suspension provisionally lifted } \\
\text { after claimant withdrew legal } \\
\text { actions and FA leadership and FA } \\
\text { control over league were } \\
\text { reinstalled }\end{array}$ \\
\hline Bosnia & 1-Apr-11 & 1-Jun-11 & $\begin{array}{l}\text { Mismanagement due to ethnic } \\
\text { divisions }\end{array}$ & $\begin{array}{l}\text { FA statutes amended according to } \\
\text { FIFA's demands }\end{array}$ \\
\hline Belize & 17-Jun-11 & 7-Jul-11 & $\begin{array}{l}\text { Failure of government to provide } \\
\text { security for national team matches }\end{array}$ & $\begin{array}{l}\text { Suspension provisionally lifted } \\
\text { due to positive developments, } \\
\text { match played outside Belize }\end{array}$ \\
\hline Cameroon & 4-Jul-13 & 22-Jul-13 & $\begin{array}{l}\text { Governmental interference: } \\
\text { Government refused to accept } \\
\text { results of FA elections }\end{array}$ & $\begin{array}{l}\text { New elections organized, finally } \\
\text { reinstallation of elected FA } \\
\text { officials }\end{array}$ \\
\hline
\end{tabular}

Sources: Minutes of the FIFA Congress and FIFA's press and media releases (cf. online appendix). 
TABLE 2 Overview of the case studies

\begin{tabular}{|c|c|c|c|c|}
\hline Case & $\begin{array}{l}\text { Time } \\
\text { frame }\end{array}$ & $\begin{array}{l}\text { Nature of governmental } \\
\text { interference }\end{array}$ & $\begin{array}{l}\text { Nature of FIFA's } \\
\text { intervention }\end{array}$ & Regulatory outcomes \\
\hline \multicolumn{5}{|l|}{ Greece } \\
\hline Greece 1 & 1993 & $\begin{array}{l}\text { Attempt to modernize } \\
\text { governance structure in } \\
\text { response to } \\
\text { commercialization and } \\
\text { match fixing }\end{array}$ & Threat of suspension & $\begin{array}{l}\text { Legislative proposal } \\
\text { abandoned }\end{array}$ \\
\hline Greece 2 & 2001 & $\begin{array}{l}\text { Attempt to give } \\
\text { government more } \\
\text { supervisory powers }\end{array}$ & Threat of suspension & $\begin{array}{l}\text { Legislative proposal } \\
\text { watered down }\end{array}$ \\
\hline Greece 3 & 2006 & $\begin{array}{l}\text { Attempt to place party } \\
\text { allies in football } \\
\text { leadership }\end{array}$ & Formal suspension & $\begin{array}{l}\text { Regulatory exemption for } \\
\text { football }\end{array}$ \\
\hline Spain & 2008 & $\begin{array}{l}\text { Formal provision on sport } \\
\text { bodies' elections }\end{array}$ & $\begin{array}{l}\text { Informal threat of } \\
\text { suspension }\end{array}$ & Non-enforcement of law \\
\hline Poland & $2007 / 08$ & $\begin{array}{l}\text { Attempt to assume interim } \\
\text { management to fight } \\
\text { corruption and } \\
\text { mismanagement }\end{array}$ & $\begin{array}{l}\text { Treat of suspension, threat } \\
\text { of withdrawal of Euro- } \\
2012\end{array}$ & \\
\hline
\end{tabular}




\section{Online Appendix}

Table A.1. FIFA's suspension of member FAs 2003 - 2013

\begin{tabular}{|c|c|c|c|c|}
\hline Member FA & $\begin{array}{l}\text { Date of } \\
\text { suspen- } \\
\text { sion }\end{array}$ & Date of lift & Trigger of suspension & Outcome of FIFA intervention \\
\hline Azerbaijan $^{\mathrm{a}}$ & 15-Apr-03 & 23-May-03 & $\begin{array}{l}\text { External pressure and repeated } \\
\text { violations of fundamental } \\
\text { principles }\end{array}$ & $\begin{array}{l}\text { Parties agreed to respect a FIFA } \\
\text { moderated agreement }\end{array}$ \\
\hline $\begin{array}{l}\text { Antigua and } \\
\text { Barbuda }^{\mathrm{b}}\end{array}$ & 20-May-03 & 29-Jun-05 & No details provided & $\begin{array}{l}\text { Suspension lifted after situation } \\
\text { had improved }\end{array}$ \\
\hline Guatemala $^{c}$ & 9-Jan-04 & 17-May-04 & $\begin{array}{l}\text { Governmental interference: } \\
\text { Government replaced FA and } \\
\text { disrespected elected FA officials }\end{array}$ & $\begin{array}{l}\text { Re-installment of elected FA } \\
\text { leadership, recognition of FAs' } \\
\text { competencies }\end{array}$ \\
\hline Kenya $^{d}$ & 2-Jun-04 & 6-Aug-04 & $\begin{array}{l}\text { Governmental interference: } \\
\text { Government replaces elected FA } \\
\text { officials because of } \\
\text { mismanagement and fraud }\end{array}$ & $\begin{array}{l}\text { Installment of a normalization } \\
\text { committee to improve } \\
\text { transparency and accountability }\end{array}$ \\
\hline Macau $^{\mathrm{e}}$ & 15-Feb-05 & 6-Mar-05 & $\begin{array}{l}\text { Governmental interference: } \\
\text { Non-specified }\end{array}$ & $\begin{array}{l}\text { Suspension lifted after } \\
\text { negotiations }\end{array}$ \\
\hline Yemen $^{\mathrm{f}}$ & 12-Aug-05 & 9-Nov-05 & $\begin{array}{l}\text { Governmental interference: } \\
\text { Non-specified }\end{array}$ & $\begin{array}{l}\text { Suspension lifted after creation of } \\
\text { a normalization committee and } \\
\text { concessions by the government }\end{array}$ \\
\hline Greece $^{\mathrm{g}}$ & 3-Jul-06 & 12-Jul-06 & $\begin{array}{l}\text { Governmental interference: } \\
\text { National legislation granting } \\
\text { professional league independence } \\
\text { from FA was not revoked }\end{array}$ & $\begin{array}{l}\text { Legislation amended according to } \\
\text { FIFA's demands }\end{array}$ \\
\hline Kenya $^{\mathrm{h}}$ & 25-Oct-06 & 9-Mar-07 & $\begin{array}{l}\text { Governmental interference: } \\
\text { Non-implementation of } \\
\text { agreements, escalation of internal } \\
\text { conflicts }\end{array}$ & $\begin{array}{l}\text { Government declares to abstain } \\
\text { from further intervention, } \\
\text { pending legal proceedings are } \\
\text { withdrawn, dissolution of } \\
\text { government's interim } \\
\text { normalization committee and } \\
\text { reinstallation of elected officials. }\end{array}$ \\
\hline $\operatorname{Iran}^{\mathrm{i}}$ & 23-Nov-06 & 20-Dec-06 & $\begin{array}{l}\text { Governmental interference: } \\
\text { Non-independence of decision- } \\
\text { making and election processes }\end{array}$ & $\begin{array}{l}\text { Creation of a transitory board and } \\
\text { future implementation of FIFA's } \\
\text { demands }\end{array}$ \\
\hline Kuwait $^{\mathrm{j}}$ & 29-Oct-07 & 20-Dec-08 & $\begin{array}{l}\text { Governmental interference: } \\
\text { Government replaced elected FA } \\
\text { officials }\end{array}$ & $\begin{array}{l}\text { Suspension provisionally lifted } \\
\text { after new elections are } \\
\text { announced, reinstallment of } \\
\text { FIFA's transition committee, } \\
\text { amendment of FA's statutes }\end{array}$ \\
\hline Albaniak $^{\mathrm{k}}$ & 14-Mar-08 & 26-Apr-08 & $\begin{array}{l}\text { Governmental interference: } \\
\text { Government initiated legal } \\
\text { proceedings against new FA } \\
\text { statutes }\end{array}$ & $\begin{array}{l}\text { Legal proceedings stopped, } \\
\text { creation of a working-group }\end{array}$ \\
\hline Madagascarl & 19-Mar-08 & 19-Мay-08 & $\begin{array}{l}\text { Governmental interference: } \\
\text { Ministerial decree dissolved FA }\end{array}$ & $\begin{array}{l}\text { Madagascan Supreme Court } \\
\text { declared decree null and void, re- } \\
\text { installment of FA }\end{array}$ \\
\hline Chad $^{\mathrm{m}}$ & 28-Mar-08 & 7-May-08 & $\begin{array}{l}\text { Governmental interference: } \\
\text { Government replaced FA officials } \\
\text { and intended to hold new } \\
\text { elections }\end{array}$ & $\begin{array}{l}\text { Decree revoked, re-installment of } \\
\text { elected FA officials }\end{array}$ \\
\hline
\end{tabular}




\begin{tabular}{|c|c|c|c|c|}
\hline $\operatorname{Iraq}^{\mathrm{n}}$ & 26-May-08 & 29-May-08 & $\begin{array}{l}\text { Governmental interference: } \\
\text { Governmental decree dissolved } \\
\text { all sport organizations }\end{array}$ & $\begin{array}{l}\text { Exclusion of FA from } \\
\text { dissolvement decree }\end{array}$ \\
\hline Ethopia $^{o}$ & 29-Jul-08 & Unknown & $\begin{array}{l}\text { Governmental interference: } \\
\text { Dismissal of elected officials, } \\
\text { non-compliance with FIFA } \\
\text { roadmap }\end{array}$ & Unknown \\
\hline Samoa $^{\mathrm{p}}$ & 24-Oct-08 & 20-Dec-08 & Repeated management problems & Unknown \\
\hline Peru $^{\mathrm{q}}$ & 25-Nov-08 & 20-Dec-08 & $\begin{array}{l}\text { Governmental interference: } \\
\text { Non-specified }\end{array}$ & Unknown \\
\hline Brunei & 29-Sep-09 & 1-Jun-11 & Governmental interference: & Conditions of FIFA Emergency \\
\hline Darussalam $^{\mathrm{r}}$ & & & $\begin{array}{l}\text { Dissolvement of FA and creation } \\
\text { of new government controlled } \\
\text { body }\end{array}$ & $\begin{array}{l}\text { Committee fulfilled and statues } \\
\text { amended according to FIFA } \\
\text { Statutes }\end{array}$ \\
\hline $\operatorname{Iraq}^{\mathrm{s}}$ & 20-Nov-09 & 19-Mar-10 & $\begin{array}{l}\text { Governmental interference: } \\
\text { Government controlled NOC } \\
\text { dissolved FA }\end{array}$ & Dissolution of FA withdrawn \\
\hline El Salvador ${ }^{\mathrm{t}}$ & 11-May-10 & 27-May-10 & $\begin{array}{l}\text { Governmental interference: } \\
\text { Government did not accept } \\
\text { FIFA's normalization committee } \\
\text { and new FA statutes }\end{array}$ & $\begin{array}{l}\text { Legitimacy of normalization } \\
\text { committee and new statutes } \\
\text { recognized }\end{array}$ \\
\hline Nigeria $^{u}$ & 4-Oct-10 & 8-Oct-10 & $\begin{array}{l}\text { Governmental interference: } \\
\text { Court actions against FA officials, } \\
\text { governmentally forced resignation } \\
\text { of officials, government started } \\
\text { league without relegation from } \\
\text { previous season }\end{array}$ & $\begin{array}{l}\text { Suspension provisionally lifted } \\
\text { after claimant withdrew legal } \\
\text { actions and FA leadership and FA } \\
\text { control over league were } \\
\text { reinstalled }\end{array}$ \\
\hline Bosnia $^{v}$ & 1-Apr-11 & 1-Jun-11 & $\begin{array}{l}\text { Mismanagement due to ethnic } \\
\text { divisions and rotating FA } \\
\text { presidency }\end{array}$ & $\begin{array}{l}\text { FA statutes amended according to } \\
\text { FIFA's demands }\end{array}$ \\
\hline Belize $^{\mathrm{w}}$ & 17-Jun-11 & 7-Jul-11 & $\begin{array}{l}\text { Failure of government to provide } \\
\text { security for national team matches }\end{array}$ & $\begin{array}{l}\text { Suspension provisionally lifted } \\
\text { due to positive developments, } \\
\text { match played outside Belize }\end{array}$ \\
\hline Cameroon $^{\mathrm{x}}$ & 4-Jul-13 & 22-Jul-13 & $\begin{array}{l}\text { Governmental interference: } \\
\text { Government refused to accept } \\
\text { results of FA elections }\end{array}$ & $\begin{array}{l}\text { Normalization committee created, } \\
\text { new elections organized, finally } \\
\text { re-installment of elected FA } \\
\text { officials }\end{array}$ \\
\hline
\end{tabular}

a. 'FIFA suspends Azerbaijan', Media Information, 15 April 2003; 'Suspension on Association of Football Federations of Azerbaijan lifted', Media Information, 23 May 2003. b. Antigua and Barbuda: '32 or 36? FIFA executive faced with crucial decisions', Media Information, 20 June 2003. c. 'FIFA suspends Guatemala Football Federation', Media Information, 9 January 2004. d. 'FIFA suspends Kenya Football Federation', Media Information, 1 January 2004; 'FIFA Emergency Committee provisionally lifts Kenyan suspension', Media Release, 6 August 2004. e. 'FIFA suspends the Macau Football Association', Media Info, 15 February 2005; 'Full support for German football association and referees', Media Release, 8 March 2005. f. 'FIFA suspends the Yemen Football Association', Media Info, 12 August 2005; 'Suspension of Yemen Football Association provisionally lifted', Media Info, 9 November 2005. g. 'FIFA suspends the Hellenic Football Federation', Media Info, 3 July 2006;'FIFA lifts suspension on Hellenic Football Federation', Media Info, 12 July 2006. h. 'FIFA suspends the Kenyan Football Federation', Media Info, 25 October 2006; 'Clear declaration to defend the autonomy of sport', Media Release, 6 December 2006. i. Iran: 'FIFA suspends Iran Football Federation', Media Info, 23 November 2006; 'FIFA lifts suspension of IR Iran Football Federation', Media Info, 20 December 2006. j. 'FIFA lifts suspension on Kuwait on 
conditional basis', Media Info, 9 November 2007. k. 'Suspension of the Football Association of Albania lifted', Media Info, 29 April 2008. I. 'Malagasy Football Association suspended', Media Info, 19 March 2008; 'Suspension of the Madagascan football association lifted', Media Release, 19 May 2008. m. Chad: 'Chadian football association suspended', Media Info, 28 March 2008; 'Suspension of the Chad football association lifted', Media Release, 7 May 2008. n. 'Iraqi Football Association suspended', Media Release, 26 May 2008, 'Suspension of Iraqi Football Association provisionally and conditionally lifted', Media Info, 29 May 2008. o. 'Ethopian Football Federation suspended', Media Info, 29 July 2008. p. 'FIFA Executive Committee Meeting in Tokyo', Media Info, 20 December 2008. q. Peru: 'Suspension of the Peruvian Football Association', Media Info, 25 November 2008. r. 'Key decisions reached in Rio', Media Release, 29 September 2009; 'The Executive Committee lifts the suspensions on Bosnia-Herzegovina and Brunei Darussalam', Media Release, 30 May 2011. s. 'FIFA Executive Committee approves special funding for Chile and Haiti', Media Release, 19 March 2010. t. 'Suspension of the Salvadoran Football Association', Media Release, 12 March 2010; 'Suspension of Salvadoran Football Association lifted', Media Release, 27 May 2010. u. 'Suspension of the Nigeria Football Association', Media Release, 4 October 2010; 'Suspension of the Nigeria Football Federation provisionally lifted', Media Release, 8 October 2010. v. Bosnia: 'Suspension of the Football Association of Bosnia-Herzegovina as of 1 April 2011 and until further notice', Circular no. 1258, 1 April 2011. w. 'Suspension of the football Association of Belize provisionally lifted', Media Release,7 July 2011. x. Cameroon: 'Suspension of the Cameroonian Football Association', Media Release, 4 July 2013; 'Suspension of the Cameroonian Football Association (Fecafoot) lifted', Media Release, 22 July 2013. 


\section{Detailed case study narratives}

\section{FIFA vs. Greece, a Long Standing Conflict}

FIFA's conflicts with Greece have prolonged since 1990. In 2006, FIFA suspended the Hellenic Football Federation (HFF) because of government interference (FIFA 2006a). The decision was reversed within a week after FIFA gained a regulatory exception for its governance domain (FIFA 2006b).

Early Conflicts. The governance framework of football in Greece was created in 1979 (Law 789/1979). The football sector did not oppose the law, as it granted public funding (Anagnostopoulos 2011; Dimitropoulos 2006; 2010). In 1993, the Greek government intended to update governance structures in the face of sport commercialization and match fixing scandals. Accordingly, the government proposed legislation to overhaul the nomination of referees for league and cup matches and the composition of sport disciplinary courts (Panagiotopoulos and Mourniakis 2006a; 2006b). The HFF did not accept the proposals and involved FIFA. FIFA threatened to suspend the HFF implying an exclusion from 1994 World Cup on grounds of excessive state intervention. The government abandoned the proposed legislation (Panagiotopoulos and Mourniakis 2006a).

Second Attempt to Regulate Greek Football Governance. In 1999 the Greek government again decided that professional sport was in need of a tighter regulatory framework, proposing a new National Sports Act (Law 2725/1999). The law intended to give the state a greater oversight in governance structures of professional sports (Dimitropoulos 2010) and detailed regulated the composition of disciplinary committees, and the election, dismissals and incompatibilities for members of the HFF board (Panagiotopoulos \& Mourniakis 2006a). After being invoked by HFF FIFA demanded the Greek government on 19 March 2001 to 'immediately refrain from interfering with the affairs of the HFF':

'This undertaking has to be made by the Greek government not later than 30 March 2001.

Furthermore, FIFA requests that the required provisions or amendments to Greek sports

legislation should be carried out and be in place by 25 April 2001.’ (FIFA 2001a)

FIFA threatened to suspend the HFF 'from all international football activities' (FIFA 2001a), including the upcoming 2002 FIFA World Cup. The Greek government responded swiftly, which 
resulted in a meeting at FIFA's Zurich headquarters chaired by President Blatter and attended by the Greek Secretary of State for Sport and the HFF Chairman (FIFA 2001b). The parties agreed to reform the Greek Sports Act 'on basis of an action plan proposed by FIFA' (FIFA 2001b).

An agreement was finally signed in August 2001. According to FIFA, the agreement normalized 'the relations between Greek football and the country's governmental authorities in line with the FIFA Statutes and regulations' (FIFA 2001c). The government was given a strict deadline to adapt the legislation by mid-January 2002. Finally, the government watered down its initial proposals and left the HFF structures mostly unchanged (Panagiotopoulos and Mourniakis 2006a; 2006b).

Third Round: FIFA Suspends Greece. After the conservative party New Democracy gained power in spring 2004 - just months before the Athens Olympics - sport became a top issue in Greek politics. Prime Minister Costas Karamanlis took personal charge of the preparations for the Olympic Games, seizing control of the culture ministry (responsible for sport) and appointing personal allies in key positions within the public sports sector (Carr 2004).

The government also proposed changes to the National Sports Act. Sport federations in the country were given six months to amend their statutes, including election systems (Panagiotopoulos and Mourniakis 2006b). The legislation appears to have been intended to assume political control of the Greek FA (Anagnostopoulos 2011, pp. 212-3). At least the incumbent HFF chairman, Vasilios Gagatsis, felt that the amendments reduced his chances for reelection. After HFF elections were finally held without changes in the electoral system, the Greek sport minister withheld all state funding of the HFF.

After another HFF complaint, FIFA, in September 2005, gave Greece a deadline of 15 July 2006 to amend the legislation (FIFA 2005a). When the government failed to comply, FIFA formally suspended the HFF with immediate effect in July 2006 (FIFA 2006a). While the Greek sports minister insisted on the government's right to regulate football governance (BBC Sport 2006), the suspension and the following social and political pressure to comply with FIFA's demands prompted the Prime Minister to intervene personally (Anagnostopoulos 2011, p. 214). Just eight days after the suspension, the Greek parliament amended the National Sports Act:

'Specifically, for the sport of football, all the subjects of functioning and organisation of the sport, the Hellenic Football Federation and its members are self-governed by the HFF and its bodies, according to its statutes and regulations, as well as those that are 
determined by the Union des Associations Européennes de Football (UEFA) and the Fédération Internationale de Football Association (FIFA), even if different regulations are provided in the law 2725/1999, as it is in effect in the athletic legislation.' (FIFA 2006b, emphasis added)

Satisfied with this opt-out granted only for football, FIFA lifted the suspension (FIFA 2006b). The fact that FIFA obtained a full exemption of the HFF from the most important piece of legislation that regulates the sport sector clearly indicates FIFA's bargaining power.

\section{FIFA vs. Spain: Informal Persuasion}

In Spain the regulation of the sports sector is laid down in the Spanish Sports Act of 1990 (Law 10/1990), complemented with subsequent ministerial orders or decrees (Puig et al. 2010). The Act includes very specific provisions regarding the governing structures of professional sport (García et al. 2011). Thus, the Act defines the roles and responsibilities of sport federations. Federations are described as private entities acting by delegation of the state (Law 10/1990, Article 30). Ultimately, conflicts with FIFA arose in the spring of 2008 when the national team had already qualified for Euro-2008.

Electoral Processes. The conflict had its origin in the regulation of the Spanish FA's (SFF) electoral process. In December 2007 the government adopted a ministerial order regulating elections in all sport federations:

'Elections will be made to coincide with the year of celebration of the Summer Olympic Games, and must start within the first quarter of this year. However, the Spanish sports federations that participate in the Summer Olympics shall begin their elections within two months from the end of the Olympic Games’ (Ministerial Order 2007, article 2).

With Spanish football not qualifying for the 2008 Olympics, the SFF was required to hold elections during the first trimester of 2008 (Expósito 2008a). However, the incumbent president, Angel Villar, proposed to organize the elections in the autumn implying non-compliance with the Ministerial Order. The conflict about a relatively minor technical detail gained increased public attention through constant reporting by the Spanish press (Expósito 2008a; Mateo 2008a, b).

FIFA's threat to the Spanish Government. In February 2008, FIFA President Blatter travelled to Madrid to pay tribute to football legend Alfredo Di Stéfano. During a press conference, Blatter commented: 
'This situation in Spain is incomprehensible. We fully support the federation and hope that the government understands the risk; FIFA's Emergency Committee could meet in just six hours by phone or electronically to suspend the federation’ (Mateo 2008a).

Blatter deemed the ministerial order an 'unacceptable intervention in football matters' and indicated possible consequences: 'It seems as if the Spanish government does not want its national team and its clubs to participate in international competitions’ (Expósito 2008a).

The Spanish Secretary of State for Sport took first a strong stance: 'I defend the sovereignty of the Spanish state and the rule of law; we shall respect and enforce the law, and Spanish sport shall be governed in Spain’ (quoted in Expósito 2008b; El País 2008). It was even suggested that administrative sanctions could be imposed upon the SFF (Suárez 2008a). However, in March 2008 the SFF Annual General Meeting decided the presidential election would be held in November that year (Carbajosa 2008; Ávila 2008). Blatter expressed his support:

'If [the Spanish government] take[s] any decision against the Spanish FA we will have to intervene, and I really do not want to do it. I hope that will not be the case' (quoted in Mateo 2008b).

Despite much talk through the press, there were no formal proceedings opened by FIFA against Spain, unlike the Greek case above. This makes harder tracing the resolution of the conflict. The elections took place on 24 November 2008, the preferred solution of the SFF and FIFA (Suárez 2008c). The government was surprisingly at ease with that decision: 'Those who think that this delay is not complying with our own ministerial order are wrong’ (quoted in González-Martín 2008). There are suggestions of a 'diplomatic pact' between the SFF President and the Secretary of State for Sport (Suárez 2008b), but there are no public explanations of the government's change of mind. Formally, the SFF presented a written submission to the government in April 2008, simply informing about the decision to hold elections in November (Iríbar 2008).

The informal character of the Spanish makes a clear-cut analysis difficult. Given the technical nature of the issue at stake, it is plausible that the government appreciated the unnecessary negative consequences that a formal FIFA intervention could have. Thus, the power of transnational football governance serves to discourage public authorities from upsetting the governing bodies. 


\section{FIFA vs. Poland: Protecting incapable governance}

Poland has also an interventionist legislative framework for professional sport (Kędzior and Szczepanik 2011). The Law on Qualified Sport of 2005 granted the Minister of Sport substantial powers over sport associations (Radke 2009). Certain business activities required ministerial approval if an association received public funding. Moreover, in case of violations of the law the minister could suspend the authorities of the association, withdraw its consent for the creation of an association or file a motion for a resolution of an association to a Polish court (Szwedo 2011, p. 63). These stipulation became relevant since corruption has been an endemic problem within Polish football. The problem's magnitude was revealed after the Polish penal code, in 2003, included the notion of 'sporting bribery'. Several hundred people including top officials of the Polish Football Association (PFA) have been charged because of match fixing and corruption (Kędzior and Szczepanik 2011; Włoch 2013).

First Round: Responding to Governance Failures. The government decided to intervene when the PFA only hesitantly addressed bribery. In January 2007 the Polish minister of sport suspended the PFA board and assumed interim management. The incumbent board deemed the measure to violate the autonomy of sport. It was supported by UEFA and FIFA, which demanded the removal of the government's supervisors. FIFA threatened the government not only with suspension but also with denial of FIFA's subsidies. FIFA demanded that the 'internationally recognized administration' of the PFA should organize elections under the supervision of UEFA and FIFA (FIFA 2007). The government was also sent signals that Poland's candidature for Euro2012 might not be considered. Thus, the government removed its supervisor (Kędzior and Szczepanik 2011, p. 211).

Second Round: Intervening with Support from Polish Sport: Eighteen months later, the government tried again to mitigate mismanagement and a hesitant approach to match fixing within the PFA (Włoch 2013). The government waited until UEFA had awarded Euro-2012 to Poland and intervened on 29 September 2008, just one day before candidates for the PFA board were to be nominated. In order to legitimize the intervention, the government asked the Polish National Olympic Committee (NOC) to nominate a supervisor (Infotuba 2008).

UEFA and FIFA refused to recognize the supervisor and asked the IOC to assess the autonomy of the Polish NOC (UEFA 2008). Furthermore, FIFA threatened Poland with exclusion 
from the 2010 World Cup and announced the cancellation of upcoming qualification matches (FIFA 2008b). Initially, the Polish Sport Minister, Miroslaw Drzewiecki was confident of convincing UEFA and FIFA that violations of the law by the PFA justified the measure (Infotuba 2008a, WPROST 2008a). However, FIFA did not accept these arguments (WPROST 2008c). UEFA even threatened to withdraw Euro-2012 from Poland (Kędzior and Szczepanik 2011, p. 212).

In a letter to the Polish Prime Minister, Donald Tusk, FIFA defined a clear deadline 'of Monday 6 October at noon' to remove the supervisor (FIFA 2008a). In response, Minister Drzewiecki demanded the PFA to respect the law and claimed: 'you cannot supervise the fight against corruption and hooliganism if you break the law yourself' (WPROST 2008d; e). Nevertheless, Drzewiecki negotiated with the incumbent PFA board. Finally, the government agreed to remove the supervisor once the independent election committee of the PFA (with participation of the Sport Ministry, FIFA and UEFA) had started preparing new elections. While the old PFA board had to admit some misconduct, the new elected board tried to suspend all further investigation into corruption within Polish football in June 2009. Although the PFA's general assembly voted the proposal down, the PFA's stance towards corruption remains questionable (Kędzior and Szczepanik 2011, p. 212).

Since the willingness to host EURO-2012 seems decisive for the actions of the government, the Polish case illustrates the positive effects that football governance system creates for its constituents. National governments are happy to exploit football's political and economic value when they can, even if they have to share regulatory powers.

\section{References}

Anagnostopoulos, C. 2011. 'The Battlefield of Greek Football: Organising top-tier Football in Greece', in H. Gammelsaeter and B. Senaux (eds), The Organisation and Governance of Top Football Across Europe. Abingdon: Routledge, pp. 207-23.

Avila, J. 2008. 'La Asamblea saca al fútbol de la ley', $A B C$, 4 March 2008, 35.

BBC Sport. 2006. 'Greece given suspension by FIFA.' BBC Sport, 4 July 2006, available at http://news.bbc.co.uk/sport1/hi/football/internationals/5141866.stm (accessed 29 May 2014).

Carbajosa, C.E. 2008. 'El fútbol desafía al gobierno', El Mundo, 4 March 2001, 51.

Carr, J. 2004. 'Leader takes on Olympic Gamble', The Times, 10 March 2004, 22.

Dimitropoulos, P. 2006. 'The Accounting and Tax Legislation of the Greek Football Clubs', Choregia Sport Management International Journal, 2, 1-2, 55-64.

Dimitropoulos, P. 2010. 'The Financial Performance of Greek Football Clubs', Choregia Sport Management International Journal, 6, 1, 5-28.

El País. 2008. 'Zapatero: La Federación de be cumplir la ley.' El País, 7 March 2008, 71.

Expósito, J. 2008a. 'FIFA amenaza: Blatter advierte que la selección y los equipos de España pueden ser vetados si se adelantan las elecciones en la federación', El Mundo, 18 February 2008, 5. 
Expósito, J. 2008b. 'Lissavetzky responde a Blatter', El Mundo, 19 February 2008, 51.

FIFA (Fédération Internationale de Football Association). 2001a. 'FIFA asks Greek Government to Refrain from Interfering with Football.' Media release, 20 March 2001. Available at http://www.fifa.com/newscentre/news/newsid=76935/ (accessed 28 May 2014).

FIFA (Fédération Internationale de Football Association). 2001b. 'Suspension of Greek FA averted after signature of joint declaration.' Media release, 30 April 2001. Available online at http://www.fifa.com/newscentre/news/newsid=774442/index.html (accessed 28 May 2014).

FIFA (Fédération Internationale de Football Association). 2001c. 'FIFA, Greek FA and Greek Government sign Agreement to normalize Situation.' Media release, 2 August 2001. Available online at http://www.fifa.com/newscentre/news/newsid=78798/ (accessed 28 May 2014).

FIFA (Fédération Internationale de Football Association). 2005a. 'FIFA Task Force to tackle current Football Problems.' Media release, 10 September 2005. Available online at http://www.fifa.com/aboutfifa/organisation/news/newsid=100056/ (accessed 28 May 2014).

FIFA (Fédération Internationale de Football Association). 2006a. 'FIFA suspends the Hellenic Football Federation.' Media release, 3 July 2006. Available online at http://www.fifa.com/worldfootball/releases/newsid=104401.html (accessed 28 May 2014).

FIFA (Fédération Internationale de Football Association). 2006b. 'FIFA lifts suspension on Hellenic Football Federation.' Media release, 12 July 2006, Available online at http://www.fifa.com/worldfootball/releases/newsid=104439.html (accessed 28 May 2014).

FIFA (Fédération Internationale de Football Association). 2007. 'Poland and Kenya warned about Governmental Interference.' Media Information, January 31, 2007. Available online at http://www.fifa.com/aboutfifa/organisation/news/newsid=110859/index.html (accessed 28 May 2014).

FIFA (Fédération Internationale de Football Association). 2008a. 'FIFA letter sets Poland Deadline. October 2, 2008.' Available online at http://www.fifa.com/aboutfifa/organisation/administration/news/newsid=895709/index.html. $\quad$ (accessed 28 May 2014).

FIFA (Fédération Internationale de Football Association). 2008b. 'Strong defence of the independence of football associations.' Media Info, 6 February 2008.

García, B., A. Palomar and C. Pérez. 2011. 'Spain: Parochialism or Innovation?', in: A. Niemann, B. García and W. Grant (eds), The Transformation of European Football: Towards the Europeanisation of the National Game. Manchester: Manchester University Press, pp. 134-151.

Infotuba (2008). 'Bezpieczne porządki w PZPN?' Infotuba, 30 September 2008. Available online at http://www.infotuba.pl/sport/bezpieczne_porzadki_w_pzpn_a3360.xml (accessed 29 May 2014).

Iríbar, A. 2008. 'Villar se sale con la suya', El País, 23 April 2008, 71.

Kędzior M. and M. Szczepanik. 2011. 'Poland: New Shape, Old Problems', in: A. Niemann, B. García, and W. Grant (eds), The Transformation of European Football: Towards the Europeanisation of the National Game. Manchester: Manchester University Press, pp. 204-19.

Mateo, J.J. 2008a. 'Blatter: El gobierno debe comprender el riesgo que corre', El País, 18 February 2008, 65.

Mateo, J.J. 2008b. 'Blatter: El Gobierno español debe dejar de ejercer presión', El País, 15 March 2008, 55.

Ministerial Order. 2007. 'Orden Ministerial ECI/3567/2007 de 4 de Diciembre que Regula los procesos electorales en las Federaciones deportivas españolas’. RCL 2007/2225, Oficial Journal 8 December 2007, 294.

Panagiotopoulos, D. and I. Mourniakis. 2006a. 'Suspension of Governing Bodies: Analysis', World Sport Law Report, 4, 7, 8-11.

Panagiotopoulos D. and I. Mourniakis. 2006b. 'Verbandsautonomie und staatliche Regulierung - Der Konflikt zwischen FIFA und Griechischem Fußballbund', Sport und Recht, 13, 5, 190-192.

Puig, N., J. Martínez and B. García. 2010. 'Sport Policy in Spain', International Journal of Sport Policy and Politics, 2, 3, 381-90.

Radke, H. 2009. 'Prawo międzynarodowych federacji sportowych a prawo krajowe', in D. Bunikowskiego and K. Dobrzenickiego (eds), Pluralizm Prawny: Tradycija, Transformacje, Wyzwania.Toruń: Wydawca, pp. 33372.

Suárez, O. 2008a. 'La solución al conflicto entre Villar y Lissavetzky se complica', El Mundo, 26 March 2008, 46.

Suárez, O. 2008b. 'Pacto "semantic” Villar-Lissavetzky: El acuerdo final pendiente de un trámite', El Mundo, 1 April 2008, 48.

Suárez, O. 2008c. 'Villar, eterno: El presidente de la federación es reelegido sin votos en contra', El Mundo, 25 November 2008, 46. 
Szwedo, P. 2011. Poland at the Gates of EURO 2012: Global Sport Governance and the Limits of the State's Autonomy. Available online at http://www.law.du.edu/documents/sports-and-entertainment-lawjournal/issues/11/FINAL-SZWEDO-FALL-2011.pdf.

UEFA (Union of European Football Associations). 2008. 'UEFA and FIFA did not recognize Nomination of "Administrator" of the Polish FA. Media Release, September 20, 2008.' Available online at http://www.uefa.com/uefa/mediaservices/mediareleases/newsid=942119.html (accessed 29 May 2014).

Włoch, R. 2013. 'UEFA as a New Agent of Global Governance: A Case Study of Relations between UEFA and the Polish Government against the Background of the UEFA EURO 2012', Journal of Sport and Social Issues, 37, 3, 297-311.

WPROST. 2008a. 'FIFA i UEFA: zawieszenie władz PZPN nielegalne.' WPROST, 30 September 2008. http://www.wprost.pl/ar/140071/FIFA-i-UEFA-zawieszenie-wladz-PZPN-nielegalne/ (accessed 29 May 2014).

WPROST. 2008c. 'FIFA nie zmiena stanowiska.' WPROST, 3 October 2008. http://www.wprost.pl/ar/140407/FIFAnie-zmienia-stanowiska/ (accessed 29 May 2014).

WPROST. 2008d. 'Drzewiecki: PZPN musi przestrzegac prawa.' 3 October 2008. http://www.wprost.pl/ar/140342/Drzewiecki-PZPN-musi-przestrzegac-prawa/ (accessed 29 May 2014).

WPROST. 2008e. 'Drzewiecki: będzie wniosek o wycofanie kuratora.' 6 October 2008. http://www.wprost.pl/ar/140636/Drzewiecki-bedzie-wniosek-o-wycofanie-kuratora/ (accessed 29 May 2014). 